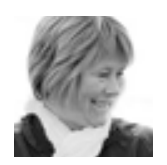

Åse Sviland,

Klinisk spesialist i pstk. Sykepleie, leder av familiepoliklinikken, psyk. divisjon, Stavanger universitetsykehus.

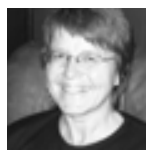

Liv Marie Iversen Strøm, Psyk. sykepleier, prosjektleder ved undervisningsavdelingen, Jæren Distriktspsykiatriske Senter, NKS.

\section{Pårørende føler seg ofte alene og tilsidesatt når et familiemedlem får en alvorlig psykisk lidelse.}

\title{
Drar lasset sammen
}

\section{Psykiatriske pasienter og deres familier som deltar i flerfamiliegrupper opplever færre tilbakefall.}

Sosial- og helsedepartementet minner stadig om at pårørende må inkluderes i behandlingen når en i familien får en alvorlig psykisk lidelse (1). Vi er to psykiatriske sykepleiere som har jobbet med flerfamiliearbeid i flere år. Vi har lyst til å dele noen av våre erfaringer $\mathrm{i}$ forhold til dette arbeidet.

\section{Bakgrunn}

I 1994 startet det et prosjekt med tidlig intervensjon ved psykoser (TIPS) ved psykiatrisk klinikk i Stavanger. I den anledning ble det vedtatt at pasienten får tilbud om behandling som innebærer medisiner, psykoterapi, sykehusinnleggelse ved behov og kunnskapsbasert familiebehandling.

Kunnskapsbasert familiearbeid har gjennom en årrekke vist seg å være meget effektivt i behandlingen av psykoser. Kombinasjonen av tradisjonelle behandlingsmetoder med deltakelse i flerfamiliegrupper mer enn halverer tilbakefallsprosenten (2).

Hovedelementene i psykoedukative flerfamiliegrupper er undervisning, kommunikasjon og problemløsning. Gruppene holdes hver fjortende dag og går over to år. Målsettingen for det første året etter et psykotisk gjennombrudd er primært å unngå tilbakefall. Samt en gradvis gjenopptakelse av vanlig rollefunksjon innen familien. Alt annet som oppnås kan sees på som bonus. Målet for andre året er å begynne den gradvise prosessen mot å komme i gang med utdannelse eller jobb, samt å gjenoppta og utvikle sosial funksjon utenfor familien. Tidsrammen som er angitt må betraktes som generell. Det vil naturligvis variere mye fra person til person når det gjelder hvor lang tid det tar å komme i rimelig bra funksjon.

\section{Erfaringer}

Vår erfaring med å inkludere familien i behandlingen har vært svært gode. Pårørende føler seg ofte alene og tilsidesatt når et familiemedlem får en alvorlig psykisk lidelse. Omstendighetene både rundt selve innleggelsen og behandlingen kan fremstå kaotisk. Situasjonen kan oppleves sterkt belastende både følelsesmessige og rent praktisk. Mange opplever skyld, skam og hjelpeløshet i forbindelse med psykiske lidelser og i møte med behandlingsapparatet. Høyt stressnivå og press over tid kan i tillegg virke ødeleggende for mange familier. Ved å delta i kunnskapsbasert flerfamiliegrupper kan både pasienten og pårørende bli bedre rustet til å mestre problemer, noe som vil gi hver enkelt opplevelse av bedre livskvalitet.

Et psykoedukativt familiearbeid anerkjenner den sterke betydningen, interessen og engasjementet som familien har, og den betydning familiemedlemmets lidelse får for deres egne liv. Siden 1997 har vi hatt 57 grupper i Stavanger og tre grupper ved Jæren DPS. Her har man fokusert på familiens signifikante betydning og ressurser.

Psykoedukasjon kan defineres som bruk av undervisningsmetoder for å hjelpe pasient og pårørende til å forstå, akseptere og håndtere sykdommen. Målet er dels å formidle viten om sykdommen og dens behandling, dels å trene opp de ferdigheter som er nødvendig for å mestre sykdommen og de problemer den medfører. Metoden er basert på oppfatningen om at viten bidrar til å bekjempe usikkerhet og maktesløshet overfor sykdommen (3).

Det spesielle med dette behandlingstilbudet er undervisningen, kommunikasjonen og problemløsningen, samt strukturen på møtene. Behandlingstilbudet drives i enkeltfamiliegrupper eller flerfamiliegrupper. Vi kjenner det best som flerfamiliegrupper.

\section{Flerfamiliegrupper}

Undervisningen skaper grobunn for ny forståelse og reduserer angst. $\mathrm{Vi}$ ser at behovet for kontroll minker. Familiemedlemmene sier at undervisningen endrer deres oppfatning av lidelsen og dermed deres atferd overfor pasienten. De pårørende blir kjent med begrepet Expressed Emotion (EE) eller «uttrykte følelser» som ofte er det utrykket de selv bruker. Det er blitt mye forsket på det følelsesmessige klima sett i sammenheng med risiko for tilbakefall, opp gjennom årene $(4,5)$.

Pårørende gir raskt gode tilbakemeldinger på utviklingen av det følelsesmessige klima i familien: «Vi har fătt det mye bedre i familien etter at vi begynte i gruppen». Vi er opptatt av å få fram hvor vanlige 
GIR NETTVERK: Gruppemøtene gjør at familiene kommer seg ut av den isolerte situasjonen de befinner seg $\mathrm{i}$. problemene er i mange familier. Det er godt å kunne kjenne likhet med hverandre innad gruppen. Å fa bekreftet at man ikke er alene.

Som gruppeledere er vi opptatt av her og nå. Vår oppgave er å dempe angst. Gjennom gruppemetoden tilrettelegger vi for struktur rundt pasienten og pårørende. På denne måten formidles trygghet og tydelighet, noe som hjelper deltakerne til å fokusere på handling i stedet for bare på følelser. Pasientene er hovedpersonene i gruppen og gruppeleder henvender seg alltid først til dem under runden. På den måten blir pasientene mer synlige. Det liker de godt. Pasientene vet at de ikke har press på seg og kan forholde seg tause dersom de ønsker det.

På rundgang setter deltakerne ord på hva som fungerer bra og hvilke utfordringer de har i hverdagen.

Den påfølgende problemløsningen, i fellesskap med familien som har tatt opp problemet, synliggjør gruppemedlemmenes engasjement og peker på likheter dem imellom. Når deltakerne lykkes med problemløsningen gir det dem håp og hjelp til å leve med sykdommen på en bedre måte. «Nå forstår foreldrene mine hvordan jeg har det».

\section{Kommunikasjon}

Denne optimismen preger i tillegg oss behandlere og bedrer samarbeidsklimaet mellom familiene og helsevesen. Fokus på den enkeltes ressurser gir trening i sosial ferdighet og innsikt, og forståelse for å finne balanse og livskvalitet på tross av lidelsen.

Når vi som gruppeledere gjentar det pasienten sier, illustrerer vi nødvendigheten av å lytte. Slik får pasientene hjelp til å gjøre seg forstått og blir støttet i egen identitetsutvikling. Deltakerne kan bli veldig engasjerte og snakke i munnen på hverandre. Dette kan skape forvirring og angst hos den enkelte pasient. Da er det viktig at vi stopper opp og minner om kommunikasjonsreglene: en om gangen og respekt for hverandre. Vår utfordring ligger i å konkretisere kommunikasjonen i gruppen og fange opp uklare budskap. Vi refererer gjerne til oss selv og våre behov når vi stopper opp i slike tilfeller der vi trenger mer klarhet i det som blir sagt. På denne måten hjelper vi også pasientene med deres konsentrasjonsproblemer: «Nå kan jeg og min datter klare å snakke sammen om det som er vanskelig. Det hadde vi ikke klart uten hjelp fra gruppen».

Det sosiale aspektet ved flerfamiliegruppene er viktig. Alle møtene starter med 15 minutters sosialt prat og dette gjentas de siste fem minuttene som avslutning. Dessuten ser vi at deltakerne blir stående sammen utenfor å knytte kontakter etter at gruppen er ferdig. Familiemedlemmene opplever en betydelig avlastning når de blir hjulpet ut av den isolerte situasjonen de ofte befinner seg i. De får økt selvfølelse når de får møte andre med sammenlignbare erfaringer. Pasientene utrykker lettelse og føler seg ikke lenger alene når de hører andre pasienter fortelle om sine opplevelser med for eksempel psykose. Opplevelse av skyld og skam reduseres når familiene får dele sine erfaringer med hverandre.

\section{Avslutning}

Dette er en metode vi har stor tro på. All forskning som er gjort til nå viser at tilbakefallsprosenten halveres (2). Vi får stadig tilbakemelding både fra pasienter og deres pårørende om at dette har de nytte av i sin hverdag. Vi får også tilbakemelding fra gruppelederne om at denne type arbeid er med på å gi dem energi, noe de igjen kan overføre til arbeidet sitt med andre pasienter. Det blir likevel en utfordring i framtiden å opprettholde entusiasmen hos gruppelederne. Dette er tross alt et arbeid de gjør på ettermiddagen utenom sin vanlige jobb.

Det er også viktig å forske i forhold til andre lidelser for å se om metoden har samme effekt her. Per i dag har vi utvidet tilbudet til grupper med bipolar lidelse, både for flerfamilie og egne pargrupper $(6,7,8)$. Vi har også pargrupper der den ene parten har en psykoselidelse. Og vi er i starfasen med å forsøke samme modell i forhold til pasienter med rusproblemer og mildere psykiske lidelser. I framtiden har vi lyst til å forsøke samme modell i samarbeid med Alderspsykiatrisk avdeling i forhold til demenslidelse.

\section{LITTERATUR}

1. Statens Helsetilsyn. Schizofreni kliniske retningslinjer. Oslo: Statens helsetilsyn, 2000: 18-24.

2. Øxnevad AL, Grønnestad T, Arntzen B. Familiearbeid ved psykoser - mot samme mål. Stavanger: Stiftelsen Psykiatrisk opplysning, 2000.

3. Kjær R, Linderoth L, Melle I. FRAM rehabilitering ved schizofreni. Oslo: AstraZeneca, 2005.

4. Magana AB, Goldstein M, Kamo M et.al. A Brief Method for Assesing Expres sed Emotion in Relatives of Psychiatric Patients. Psychiatric Research 1986; 17 : 203-213.

5. Kavanagh DJ. Recent developments in Expressed Emotion and Schizophrenia. British Journal of Psychiatry 1992; 160: 601-620.

6. David A, Moltz MD. Bipolar Disorder and the family: An Integrative Model Fam Proc 1993; 32: 409-423.

7. Goldstein MJ, Miklowitz DJ. The effectiveness of psychoeducational family therapy in the treatment of schizophrenic disorders. J Nerv Ment Dis 1995; 21 : $361-76$.

8. Clarkin JF, Carpenter D, Hull J, et.al. Effects of psychoeducatioal intervention for married patiens with bipolar disorder and their spouses. Psychiatr Serv 1998; 49: 531-533. 